\title{
Differences in the usefulness of communication channels, as experienced by gender and ethnic groups during their university selection process
}

\author{
M Wiese, Y Jordaan and CH van Heerden*
}

\begin{abstract}
Recruiting students to enrol at a particular institution is becoming a competitive and challenging process for higher education institutions. Therefore, institutions should create efficient and effective ways of providing relevant information to prospective students during their process of selecting an institution. The major communication channels that prospective students consult during their selection process, and the usefulness thereof for students, are important knowledge imperatives for higher education institutions. In this study, 12 different channels of communication, considered by students during a typical higher education institution selection process, were investigated. A non-probability convenience sample of 1241 first-year students from six higher education institutions in South Africa was drawn. Findings suggest that female students attach a significantly higher value to nine of the 12 communication channels, compared to their male counterparts. There were also differences between the ethnic groups in terms of the usefulness of events on campus, high school teachers, open days and campus visits, as well as university publications. Higher education institutions can use the results to develop communication strategies that are more student oriented, in order to reinforce their image and to reach students more effectively through the appropriate communication channels.
\end{abstract}

Key words: Communication channels, ethnic group, gender, higher education, selection process, students

\section{INTRODUCTION}

Numerous pressures and changes in the higher education landscape have driven local and international higher education institutions to use their resources more effectively (Espinoza, Bradshaw and Hausman 2002; Maringe 2006; Mouwen 2002; Rindfleish 2003; Whyte 2001). Some of these challenges include an increase in competition from public and private education service providers, a decrease in government funding for higher education institutions, an increase in marketing costs, changes in terms of mergers and student profiles, and a propensity for the nonpayment of student fees.

Higher education institutions are dependent on a continuous and increased flow of students and funds and, therefore, communication to its target market is of crucial importance. In choosing an institution, students seem to be strongly influenced by both the information that the institution provides, and the channels through which the information is provided. In this regard, institutions need to reach students through the most cost-effective and appropriate channels. According to Goff, Patino and Jackson

\footnotetext{
* Dr M Wiese, Prof Y Jordaan, and Prof $\mathrm{CH}$ van Heerden lecture in the Faculty of Economic and Management Sciences, Department of Marketing and Communication Management, University of Pretoria, South Africa. Email: melanie.wiese@ up.ac.za
} 
(2004: 795), an increase in advertisements, promotions and other marketing efforts is needed to effectively communicate with prospective students. An imperative here is to know how to reach them and what to say to them. This imperative is especially true for South African higher education institutions that have a diverse student body. Higher education institutions will have to address these heterogeneous target markets using communication strategies that accommodate differences (Bonnema \& Van der Waldt 2008: 315).

Early research by Chapman (1981), which was replicated by other authors, found that higher education institutions use various communication channels to market their services, including word-of-mouth, web pages, open days, brochures, alumni networks and advertisements in newspapers, on radio and television (Arpan, Raney and Zivnuska 2003; Bradshaw, Espinoza and Hausman 2001; Seymour 2000).

Espinoza, Bradshaw and Hausman (2002: 20) state that in response to the pressures of the changing environment, higher education institutions have to strategically focus on the prospective student market to understand and influence their decision to choose a higher education institution. It is surmised that the supply of information to this market will positively influence students' selection processes.

Few higher education institutions use only one medium of communication and most prefer a combination or integration of several communication methods. Although higher education institutions have a variety of communication mix elements at their disposal, the challenge is to achieve a balanced mix that is cost-effective, while taking budget constraints into consideration. Apart from understanding the needs and preferences of students, the communication channels that students consult to obtain information are also important when developing a communication strategy.

The purpose of this study is to investigate the usefulness of school visits, institution publications, websites, campus visits, word-of-mouth (friends, alumni, school teachers), advertisements (radio, television, magazines) and events on campus, as channels of communication for different socio-demographic groups.

\section{UTERATUREREVEW}

\section{The role of communication in higher education}

Communication between higher education institutions and their stakeholders has been changing and substantially improving due to a changing society, corporate values, information technology, enhanced connectivity and shared values among nations (Ihator 2004: 251). Integrated marketing communications (IMC) is a process of managing all sources of information about a product/service to which a customer or prospect is exposed, which behaviourally moves the customer toward a sale and maintains customer loyalty (ibid.: 249). IMC has an increasing need for integration and the need for 
organisations to devise and implement unified and integrated communications programmes. Zeithaml and Bitner (2000: 405) suggest that a more complex integrated form of communication is needed for service products (such as education), hence the Integrated Services Marketing Communication (ISMC) approach. This concept requires a complete communication strategy that involves staff, every interface the institution has with its students, stakeholders and the community at large (Jones 2002: 450; Laurer 2006).

This need for integration has led to integrated communication (IC) becoming an important marketing issue, since IC is broader than IMC or ISMC, which tends to assume that integration takes place, or should take place, within the realm of marketing (Christensen, Firat \& Torp 2008: 424). IC will enable higher education institutions to build a brand relationship with all stakeholders, by emphasising both the corporate integrity of the organisation and the service product offering. The scope of IC has been broadened to include virtually everything an organisation says and does, and everyone who is affected by the organisation's existence and activities (Torp 2009: 203).

Worth noting is the role of corporate branding in motivating stakeholder groups to take an interest in the higher education institution. One way to survive in competitive markets is to adopt a corporate branding strategy to enhance and sustain distinctiveness through linking corporate characteristics to products and services (Anisimova 2007: 395). Although corporate branding falls beyond the scope of this study, the alignment of corporate identity and image with all communication activities, as well as its role in the integrated communication process, is acknowledged. Higher education institutions should take cognisance of the ultimate goal of the institutional brand, namely to create meaning and value through various relationships between the higher education institution and its multiple stakeholders (Tarnavoskaya, Elg \& Burt 2008: 945). This is mainly because of the ability of the institutional brand to influence the perceptions, behaviour and decision making of the different stakeholder groups, including prospective students.

\section{The communication process}

Most non-profit organisations (such as higher education institutions) serve several stakeholders, of which two broad groups can be identified, namely donors and clients (Lovelock \& Wright 2002: 233). Donors may include individuals, trusts, companies or governmental bodies. The second group consists of clients such as students (current and prospective), parents, alumni, the media, employers and/or staff.

Most consider students to be the primary clients of higher education institutions, with parents, employers and society as secondary beneficiaries. For the purpose of this study, the focus falls on a higher education institution's communication with prospective students. This does not imply that institutions do not need to communicate with other stakeholder groups such as alumni, parents, donors, government or the general public. What is imperative is that the message to the prospective 
student should be the same, regardless of the communication channel used or the stakeholder group communicated to.

In order to ensure effective communication, higher education institutions need to understand the communication process. Communication involves the creation of shared meaning between participants. The intangibility, inseparability, perishability and heterogeneity of services create special communication requirements and involve the risk of miscommunication that is not so evident in the marketing of physical goods (McColl-Kennedy 2003: 236). Communication can be viewed as the transfer of a message from a sender (higher education institution) to a receiver (prospective student, existing students, parents, employers and/or alumni) via a channel or medium. The sender translates his/her objectives, ideas and concepts through language into a message, which is known as encoding (Strydom, Jooste, Du Plessis \& Cant 2006). The receiver tries to decode the message before (s)he can comprehend its meaning, and then reacts or responds to the message (Lamb, Hair, McDaniel, Boshoff \& Terblanche 2004: 326). The disturbances (physical or psychological) that prevent the successful transfer of the message are known as noise - something which influences all the components of the communication process and can negatively influence effective communication.

According to Jones (2002: 44), students' ability to decode the message is influenced by their past experiences, feelings, emotions, attitudes and perceptions of the institution. Thus, higher education institutions need to fully understand their target market to identify the appropriate intended messages. The communication process provides higher education institutions with the opportunity to influence prospective students' decision making by developing a message that creates awareness, positions themselves in the mind of the student, changes students' attitudes towards the institution, or encourages students to select the institution (Jones 2002: 45). Higher education institutions should use communication channels that will attract attention, arouse interest and present the message clearly (Kotler \& Fox 1995: 353).

\section{The higher education institution selection process}

The increasingly diverse South African student market has compelled higher education institutions to become more marketing focused. This has resulted in a growing interest by higher education institutions in students' choice and decision making, especially given the increased competitive environment that offers students a wider range of options from which to choose (Maringe 2006: 467). It is postulated that prospective higher education students in South Africa go through an extensive decision-making process when applying for a course of study. This process commences in Grade 9, when learners have to make a choice of subjects, and continues to Grade 12. These selected subjects play a role in the career paths of learners, as they form part of the entrance requirements for higher education and the prerequisites for certain programmes. Learners normally only enquire about institutions and programmes when they reach Grade 11 or 12. 
Many higher education institutions seem to take an aggressive marketing position in an attempt to directly influence prospective students' decision making (Ivy 2001: 276; Ross, Heany \& Cooper 2007: 595). Choosing a higher education institution is a complex and multifaceted process involving a range of influences that have a bearing on decision making. Decision making is broadly seen as a problem-solving process undertaken by applicants in the process of making choices (Maringe 2006: 468). Several researchers have devoted attention to the issue of selecting a higher education institution (Braxton 1990; Hossler \& Gallagher 1987).

Many models of decision making have been developed to explain consumers' decision-making processes and are generally seen as encompassing a series of stages (Maringe 2006: 468). Building on the work of others, Hossler and Gallagher (1987) created a three-stage model to describe the institution selection process of students. These stages include a predisposition stage, a search stage and a choice stage. In the predisposition stage, learners determine whether they will continue their formal education. In the search stage, prospective students search for information and consider the various higher education institutions available, then evaluate them according to certain criteria, known as choice factors. Interested prospects finally enter a choice stage when they submit their application to a selected institution/s.

It is during the search stage of the selection process where the gathering of information and the organisation thereof within the individual's frame of reference, begins (Du Plessis \& Rousseau 2005: 87). The investigation of students' search processes is highly important to institutions, because it can influence their marketing strategies - especially their communication strategies. Two types of consumer search processes can be identified, namely internal and external searches. Internal search occurs when a consumer attempts to retrieve information from his/her long-term memory on products and services that may assist in addressing the need. In contrast, external search involves acquiring information from any outside sources (Hawkins, Best \& Coney 2004: 530).

A decision about higher education can be considered as high involvement, because it has long-term consequences (future career, friendships and life satisfaction), involves major sacrifice (expensive and time consuming) and has high risk (failure or the possibility of no employment). As the prospective first-year student usually does not have much prior knowledge of higher education, (s)he will rely extensively on an external search for information. It is, therefore, important for higher education institutions to understand which channels of communication have credibility and will be consulted during such an external search.

\section{Communication channels used by prospective students}

This study investigates the usefulness of school visits, institutional publications, websites, campus visits, word-of-mouth (friends, alumni, school teachers), advertisements (radio, television, magazines and newspapers) and events on campus, as channels of communication. Hawkins, Best and Coney 
(2004: 530) note that the consumer decides how many and which channels of communication to use. The recollection of past experiences might provide the consumer with adequate information to make present choices (Schiffman \& Kanuk 2004: 556). However, first-time users usually engage in an extensive search of external sources to enrich their information base. Various communication channels exist: word-of-mouth (personal sources) such as friends, family, career guidance teachers, reference groups and opinion leaders; independent sources such as consumer groups, government agencies, the Internet and service experts; marketing communication channels such as sales personnel, advertising, websites or brochures of the organisation; and experiential sources such as organisational visits (Hawkins, Best \& Coney 2004: 530). Word-of-mouth, marketing communication channels and experiential channels will be highlighted due to their relevance to the study.

\section{Campus visits and open days (experiential channels)}

Coetzee and Liebenberg (2004: 70) suggest that prospective students make use of experiential channels of communication, such as campus visits and open days. The authors also note that prospective students attach high importance to activities on campus as a channel of communication, and their respondents indicated that they were more willing to attend an exhibition or open day to secure first-hand information than they were to rely on mass media. Hesel (2004) states that trips to higher education institutions (open days and campus visits) help potential applicants decide which institutions are best for them.

\section{Personal channels}

Personal channels refer to communication shared by friends, family or reference groups, and are known as word-of-mouth. Zeithaml and Bitner (2000: 32-33) state that the service industry recognises the strong influence of word-of-mouth. Word-of-mouth as a personal source gives the consumer the opportunity to reduce risk, because immediate feedback is available. Friends, family and peer groups may all give advice, whether based on experiences, knowledge or opinion. Research shows that when purchasing a service product such as education, students rely to a greater extent on personal sources, such as word-of-mouth by friends, family, opinion leaders and teachers, because the mass media convey very little about experience qualities (Jones 2002: 76). A study conducted by Cosser and Du Toit (2002: 2) determined that the family has a high degree of influence in the selection process especially in encouraging students to continue to study. Many people, such as friends, alumni, faculty members and parents of students have an influence on the selection of an institution (Kotler \& Fox 1995: 25 8) and consumers prefer personal communication channels to impersonal communication channels (Mitra, Reiss \& Capella 1999: 223). Previous research findings also show that discussions with relatives and friends are well used by high school learners as channels of information (Cosser \& Du Toit 2002: 101). 


\section{Marketing communication channels}

Marketing communication channels, such as advertisements, websites, e-mail and brochures, are also used by prospective students to obtain information. Chester (2005) is of the opinion that higher education institutions must consider placing press releases or articles on search engines such as Google, as these are highly visible. Evidence suggests that students use search engines as a tool for finding higher education institutions (Seymour 2000: 11). Various research studies identified that a variety of marketing channels are used by universities, such as catalogues, magazines, guidebooks and private counsellors (McDonough 1994: 427; Warren 1994). Some popular, well-known universities obtain awareness mainly from word-of-mouth by students and alumni, while less-known institutions must market themselves more aggressively and may even make use of advertising agencies to help them project the right image to students (Gemma 2002).

Weidlich (2001) argues that although higher education institutions may not be ready to abandon all print communications, they must ensure that they can communicate electronically if they want to stay competitive. The author suggests that higher education institutions make use of e-mail as a relationship-building tool, with cost-saving benefits, to recruit students. According to a press statement by the Primary Research Group (2007), more than 47 per cent of American universities use web advertising to market their institutions. In one South African study, websites were identified as one of the most useful channels of communication used by South African students (Coetzee \& Liebenberg 2004: 70).

According to Jones (2002: 56), higher education institutions are spending more on advertising as competition increases. Since higher education is directed at a specific target market, most institutions' advertising expenditure is spent on print in newspapers, journals or posters. Radio advertising is also a useful medium, as it is can be geographically segmented to reach specific audiences. Internet, websites and short message system (SMS) technology are popular media, as students can communicate directly with higher education institutions to obtain information (ibid.).

Various researchers report conflicting results on which communication channels are most useful to students. Hoyt and Brown (2003: 4) identified websites as the most important channel of communication for students, while research by Seymour (2000: 11) showed campus visits to be the most influential. Local studies by Jones (2002) highlighted word-of-mouth from friends as the most important channel of communication, while Coetzee and Liebenberg (2004) identified open days and websites as the most important channels of communication, as considered by students.

Whatever communication channel is selected, higher education institutions need to use a channel that will attract attention, arouse interest and present the message clearly (Kotler \& Fox 1995: 353). In light of the discussion, it is evident that knowledge on the information search patterns of students should be important to institutions. The channels of communication and the usefulness attached to each channel will influence the strategies institutions need to follow, to ensure that students come into contact with information about their institutions. Sound communication strategies should take into account the nature of the information search engaged in by the target market. According to Wells 
(1996: 362), institutions want consumers to include their services/brands in their evoked set, i.e. the brands the consumer considers as a possible solution to his/her need or problem (Schiffman \& Kanuk 2004: 559). Therefore, higher education institutions must ensure that prospective students are aware of their service products and the needs that their service products can satisfy.

\section{RESEARCHOBJECTIVESANDHYPOTHESES}

Little is known about the communication channels which South African students consult when considering a higher education institution. The broad objectives of this study are: to investigate how ethnic and gender groups differ regarding their perceptions of the usefulness of communication channels; and to determine how ethnic and gender groups rank the usefulness of communication channels in their selection of higher education institutions.

The following hypotheses were formulated to address the research objectives:

$\mathrm{H}_{1}$ : Black and white students differ regarding their perceptions of the usefulness of communication channels.

$\mathrm{H}_{2}$ : Male andfemale students differ regarding their perceptions of the usefulness of communication channels.

\section{METHOD}

\section{Sampling}

A total of six higher education institutions agreed to participate in the study and the fieldwork was conducted early in the academic year, to ensure that students could recall what influenced their selection process.

Non-probability convenience sampling was used, as the sample members were chosen on the basis of being available or accessible during normal lecture periods. To avoid the potential bias of using non-probability sampling, the questionnaire was administered at the six different higher education institutions, at different times, by different lecturers who acted as fieldworkers/interviewers.

In total, 1500 questionnaires were distributed - 250 to each of the six higher education institutions. An overall response rate of 83 per cent was achieved, as 1241 of the distributed 1500 questionnaires were completed.

\section{Measuring instrument}

A self-completion questionnaire was used to collect the data. The ASQ (Admitted Student Questionnaire) and CIRP (The Cooperative Institutional Research Programme) measurement scales were adapted to the South African context. 
A 5-point Likert scale was used to measure the usefulness of communication channels. Each scale item had five response categories, ranging from very poor (1), poor, fair, good to excellent (5). Provision was also made for 'not applicable' responses, to ensure that respondents were not forced to rank a communication channel they had no experience of.

\section{Data analysis}

The hypotheses were both non-directional hypotheses, and the multiple analysis of variance (MANOVA) was used to test these hypotheses, followed by univariate tests, where necessary. Assumptions of using MANOVA were violated, but these violations have little impact on larger sample sizes (Hair et al. 2006: 388; Tabachnick \& Fidell 2001: 329). As the sample size of this study was 1 241, it was decided to continue with the MANOVA, despite its violations of the assumptions.

The Wilks' lambda was the test statistic used to assess the overall significance of the MANOVA, because it is considered to be one of the tests that are most immune to violations of the assumptions underlying MANOVA, without compromising on power (Hair et al. 2006: 413). Since the multivariate test of MANOVA shows only an overall significant difference and does not determine where a significant Wilks' lambda result was found, it was followed by univariate analyses to reveal differences between groups on each of the identified communication channels.

\section{RESULTS}

\section{Respondent profile}

Females represented 64 per cent of the sample, while the majority of the respondents (75\%) were younger than 20 years. The large percentage of students between the ages of 17 and 19 years correlates with a typical sample of first-year students. The majority of students were from the white and black ethnic groups. In the sample, 46 per cent (558) of the 1241 respondents were white, 41 per cent (493) black, nine per cent (108) Indian, three per cent (34) coloured and one per cent (13) from other ethnic groups. Due to the limited number of respondents in the Indian, coloured and other categories, these groups were not included in further statistical testing. Twenty-one per cent (249) of the respondents were enrolled at the University of Pretoria (UP), 19 per cent (227) at the Tshwane University of Technology-Witbank campus (TUT), 18 per cent (227) at the University of the North-West (UNW), 16 per cent (196) at the University of Johannesburg (UJ), 15 per cent (188) at the University of the Free State (UFS), and 11 per cent (141) at the University of KwaZulu-Natal (UKZN). Although each university received the same number of questionnaires (250), due to the convenience sampling method used, the sample sizes at the various institutions differed slightly. 


\section{Hypothesis 1}

Hypothesis 1 involves a comparison between two ethnic groups, namely, 'white' and 'black' on a construct labelled as 'usefulness of communication channels'. The mean values of the two ethnic groups and the MANOVA results of the hypothesis test are shown in Table 1. Significant results are indicated in bold.

Table 1: Mean values and MANOVA results for different ethnic groups

\begin{tabular}{|l|r|r|r|}
\hline COMMUNICATION CHANNEL & \multicolumn{1}{c|}{ White } & \multicolumn{1}{c|}{ Black } & Univariate analysis \\
\hline School visits & 3.64 & 3.48 & 0.066 \\
\hline University publications & 3.77 & 3.98 & $\mathbf{0 . 0 0 1}$ \\
\hline University websites & 3.89 & 3.99 & 0.148 \\
\hline Campus visits \& open days & 4.07 & 3.94 & $\mathbf{0 . 0 4 5}$ \\
\hline Alumni & 3.62 & 3.54 & 0.208 \\
\hline Parents & 3.47 & 3.47 & 0.994 \\
\hline High school teachers & 3.35 & 3.62 & $\mathbf{0 . 0 0 0}$ \\
\hline Word-of-mouth & 3.80 & 3.69 & 0.082 \\
\hline Advertisements on radio & 3.05 & 3.11 & 0.541 \\
\hline Events on campus & 3.83 & 3.29 & $\mathbf{0 . 0 0 0}$ \\
\hline Advertisements in magazines/newspapers & 3.27 & 3.38 & 0.179 \\
\hline Advertisements on TV & 2.58 & .68 & 0.271 \\
\hline Wilks' lambda (F-value) & & & \\
\hline$\quad \mathbf{5 . 7 9 9}$ & & & \\
\hline
\end{tabular}

The Wilks' lambda value indicates a significant difference $(p=0.000)$ between ethnic groups in terms of the usefulness they attach to the different communication channels. The null hypothesis was thus rejected, as there is support for $\mathrm{HI}$.

The follow-up univariate analyses revealed that these differences were significant for four of the 12 communication channels, namely: events on campus, high school teachers, open days, and campus visits and university publications. Although university publications are useful to both ethnic groups, they were significantly more useful for black students (3.98 versus 3.77). Campus visits and open days were the most useful communication channels for white students, while black students preferred university websites. Black students perceived high school teachers as significantly more useful (3.62) than white students did (3.35). Events on campus seemed to be more useful to white students (3.83) than to black students (3.29).

Higher education institutions may find it valuable to take note of the ranking orders of the usefulness of the communication channel, as expressed by each ethnic group. Table 2 shows the ranking orders (based on mean values) for both black and white respondents. 
Table 2: Rank order of communication channels per ethnic group

\begin{tabular}{|l|l|l|l|l|}
\hline & White & Mean & Black & Mean \\
\hline $\mathbf{1}$ & Campus visits \& open days & $\mathbf{4 . 0 7}$ & University websites & 3.99 \\
\hline $\mathbf{2}$ & University websites & 3.89 & University publications & $\mathbf{3 . 9 8}$ \\
\hline $\mathbf{3}$ & Events on campus & $\mathbf{3 . 8 3}$ & Campus visits \& open days & $\mathbf{3 . 9 4}$ \\
\hline $\mathbf{4}$ & Word-of-mouth & 3.80 & Word-of-mouth & 3.69 \\
\hline $\mathbf{5}$ & University publications & $\mathbf{3 . 7 7}$ & High school teachers & 3.62 \\
\hline $\mathbf{6}$ & School visits & 3.64 & Alumni & 3.54 \\
\hline $\mathbf{7}$ & Alumni & 3.62 & School visits & 3.48 \\
\hline $\mathbf{8}$ & Parents & 3.47 & Parents & 3.47 \\
\hline $\mathbf{9}$ & High school teachers & $\mathbf{3 . 3 5}$ & $\begin{array}{l}\text { Advertisements in magazines/ } \\
\text { newspapers }\end{array}$ & 3.38 \\
\hline 10 & $\begin{array}{l}\text { Advertisements in magazines/ } \\
\text { newspapers }\end{array}$ & 3.27 & Events on campus & 3.29 \\
\hline 11 & Advertisements on radio & 3.05 & Advertisements on radio & 3.11 \\
\hline 12 & Advertisements on TV & 2.58 & Advertisements on TV & 2.69 \\
\hline
\end{tabular}

Note: The communication channels that showed significant differences in the hypothesis testing are highlighted in bold.

It can be observed from Table 2 that neither ethnic group found information from mass media very useful. For both white and black students, the usefulness of parents (eighth) and word-of-mouth (fourth) were ranked the same. Both groups also gave very similar ranking orders for school visits, websites and alumni. The most prominent differences lie in the ranking of events on campus, high school teachers and university publications (which are in line with the hypothesis test results). University publications, for example, received a higher ranking by black students than by white students.

\section{Hypothesis 2}

Hypothesis two concerned the comparison between the two gender groups on a construct labelled 'usefulness of communication channels'. The mean values of the two gender groups and the MANOVA result of the hypothesis test are shown in Table 3. Significant results are indicated in bold. 
Table 3: Mean values and MANOVA results for different gender groups

\begin{tabular}{|l|l|l|l|}
\hline COMMUNICATION CHANNEL & Male & Female & Univariate analysis \\
\hline School visits & 3.32 & 3.62 & $\mathbf{0 . 0 0 0}$ \\
\hline University publications & 3.73 & 3.87 & $\mathbf{0 . 0 2 1}$ \\
\hline University websites & 3.81 & 3.96 & $\mathbf{0 . 0 1 5}$ \\
\hline Campus visits \& open days & 3.85 & 4.06 & $\mathbf{0 . 0 0 1}$ \\
\hline Alumni & 3.47 & 3.62 & $\mathbf{0 . 0 1 5}$ \\
\hline Parents & 3.32 & 3.51 & $\mathbf{0 . 0 0 7}$ \\
\hline High school teachers & 3.24 & 3.59 & $\mathbf{0 . 0 0 0}$ \\
\hline Word-of-mouth & 3.64 & 3.77 & $\mathbf{0 . 0 3 4}$ \\
\hline Advertisements on radio & 2.97 & 3.11 & 0.097 \\
\hline Events on campus & 3.45 & 3.57 & 0.155 \\
\hline Advertisements in magazines/newspapers & 3.18 & 3.31 & 0.087 \\
\hline Advertisements on TV & 2.48 & 2.67 & $\mathbf{0 . 0 3 0}$ \\
\hline Wilks' lambda (F-value) & & & \\
\hline $\mathbf{2}$ (p-value) & & & \\
\hline
\end{tabular}

From Table 3 it is evident that the Wilks' lambda value indicates a significant difference $(p=0.007)$ between males and females in terms of the usefulness of communication channels. The null hypothesis was thus rejected, as there is support for $\mathrm{H}_{\mathrm{r}}$ The follow-up univariate analyses revealed that these differences were significant for nine of the 12 communication channels, namely: school visits, university publications, university websites, campus visits and open days, alumni, parents, high school teachers, word-of-mouth and advertisements on television.

From the results, one can conclude that female students attach a significantly higher value to most of the communication channels compared to males and it seems that females find communication channels to be more useful overall. This may, however, be a result of different response styles exhibited by gender groups. Therefore, it was decided to investigate the ranking orders of the gender groups. Table 4 portrays how males and females ranked the usefulness of each communication channel. 
Table 4: Rank order of communication channels per gender group

\begin{tabular}{|l|l|l|l|l|}
\hline & Male & Mean & Female & Mean \\
\hline $\mathbf{1}$ & Campus visits \& open days & $\mathbf{3 . 8 5}$ & Campus visits \& open days & $\mathbf{4 . 0 6}$ \\
\hline $\mathbf{2}$ & University websites & $\mathbf{3 . 8 1}$ & University websites & $\mathbf{3 . 9 6}$ \\
\hline $\mathbf{3}$ & University publications & $\mathbf{3 . 7 3}$ & University publications & 3.87 \\
\hline $\mathbf{4}$ & Word-of-mouth & $\mathbf{3 . 6 4}$ & Word-of-mouth & $\mathbf{3 . 7 7}$ \\
\hline $\mathbf{5}$ & Alumni & $\mathbf{4 . 4 7}$ & School visits & $\mathbf{3 . 6 2}$ \\
\hline $\mathbf{6}$ & Events on campus & 3.45 & Alumni & $\mathbf{3 . 6 2}$ \\
\hline $\mathbf{7}$ & School visits & $\mathbf{3 . 3 2}$ & High school teachers & $\mathbf{3 . 5 9}$ \\
\hline $\mathbf{8}$ & Parents & $\mathbf{3 . 3 2}$ & Events on campus & 3.57 \\
\hline $\mathbf{9}$ & High school teachers & $\mathbf{3 . 2 4}$ & Parents & $\mathbf{3 . 5 1}$ \\
\hline 10 & $\begin{array}{l}\text { Advertisements in magazines/ } \\
\text { newspapers }\end{array}$ & 3.18 & $\begin{array}{l}\text { Advertisements in magazines/ } \\
\text { newspapers }\end{array}$ & 3.31 \\
\hline 11 & Advertisements on radio & 2.97 & Advertisements on radio & 3.11 \\
\hline 12 & Advertisements on TV & $\mathbf{2 . 4 8}$ & Advertisements on TV & $\mathbf{2 . 6 7}$ \\
\hline
\end{tabular}

The findings depicted in Table 4 show that both males and females attach the highest value to the usefulness of campus visits and open days. Interesting to note is that both gender groups' top four lists are identical, despite these groups being identified as significantly different regarding their perceptions of the usefulness of these four communication channels. Closer inspection reveals that very few differences are evident (except perhaps in the middle-order ranking between channels five and nine), showing similar ranking preferences. This suggests that the results of Hypothesis 2 should be interpreted with caution, as differences in response styles may have contributed to the significant hypothesis test result.

\section{MANAGERIAL IMPLICATIONS}

Managerial implications are considered from the aspect of institutional marketing practitioners in reaching prospective student groups. The findings of this study showed that events on campus and open days seem to be more useful to white students (who ranked it third), while black students do not find those events very useful and only ranked them 10th (perhaps because of logistics). High school teachers are found to be more useful to black students, as they ranked them fifth, compared to ninth place on the white students' lists. University publications also received a much higher ranking by black students than white students. The ranking results are supported by the significance tests of the usefulness of events on campus, high school teachers, university publications and campus open days. The findings suggest that institutions should use university publications and high school teachers to reach their black market, and utilise campus visits, open days and events on campus to reach the white 
market. Results show a need to develop market segmentation strategies that recognise the growing diversity of the higher education recruitment market.

The findings of this study further suggest that providing information through the mass media may not be very useful to prospective students when they have to make a decision on selecting a university for further studies. However, it is important to understand that the positioning of the higher education institution not only depends on the communication strategy and market segments served, but also on the institutional brand or image. An institutional brand is best built through mass media advertising and will affect the likelihood of individuals attending a higher education institution (Ivy 2001: 276). It has been noted that the corporate brand plays a fundamental role in shaping the behaviours of stakeholders (Tarnovskaya, Elg \& Burt 2008: 946). The fact that students do not consider mass media as useful in their choice and decision making may not signal that these channels are inadequate or misleading, but that the channels may not communicate the detail they need in order to make a decision. It is thus very important that higher education institutions continue to build a strong brand as part of their overall communication strategy.

The significance testing for gender differences showed that female students perceived nine of the 12 channels to be more useful than their male counterparts did. However, the rankings showed that males and females consider the usefulness of the different communication channels to be more or less the same. As mentioned earlier, this may be a result of different response styles exhibited by gender groups, and it also raises the question whether the small differences in mean values (although statistically significant) are practically significant. Despite the results from Hypothesis 2, one would tend to suggest that both males and females can be reached effectively by higher education institutions if they provide the relevant information at their campus open days, on their websites and/or through university publications. The managerial implication of all the gender analyses does not suggest different communication channels and/or approaches for males and females, as was the case with the ethnic groups.

Overall, the findings show a higher importance being attached to information channels that have a direct link with the institution, such as campus visits and open days, institutional publications and university websites. The fact that students consider institutional sources of information to be more useful may suggest that they find these sources as being rich in information and/or trustworthy in terms of their decision making. The findings also indicate opportunities to exploit new channels more, such as providing information on websites. One advantage of websites is that they are widely available to all prospective students. This may serve as a differentiating factor when competing with other higher education institutions. The importance of the usefulness of websites (irrespective of ethnic or gender orientation) clearly indicates a move towards the increased use of technology for communication and recruitment purposes. This suggests that higher education institutions may need to consider ways of promoting themselves that are in line with the sources consulted by the recruitment market. 
It should be clear that higher education institutions should change from a 'one-size-fits-all' approach, to one that will both recognise the increasing diversity of the market as well as the greater involvement of applicants in the choice processes resulting from the competitive higher education environment. Considering higher education institutions' limited budgets for recruitment, it is important to select the most appropriate channels for communicating with prospective students. However, it is also important to follow an integrated communication approach that includes a clear understanding of the value of customers, enabling the expenditure of communication resources and effort according to the return on customer investment.

\section{LIMITATIONS AND DIRECTIONS FOR FUTURE RESEARCH}

The study was limited to students from six universities located in five provinces, thereby excluding students from other higher education institutions. It was also limited to first-year Economic and Management Sciences students, thus excluding students from other faculties. The study had a retrospective focus, as the sample population was first-year students who had to report on how they made their higher education selection the previous year. First-year students acted as 'substitutes' for Grade 11 and 12 learners, because gaining access to school learners proved problematic. Due to the nature of non-probability sampling, the respondents used in this study are not representative of the broader South African student population. Therefore, the results cannot be generalised to the entire population. It is suggested that future studies attempt to draw a representative sample from all higher education institutions.

Future research could investigate the channel selection process of students from other fields of study, to determine whether there are similarities with the main findings of this study. Studies could also determine the similarities or differences between South African students and students from other countries, in terms of their perceptions of the usefulness of different channels for decision making. Future work may also investigate the role of the institutional brand in students' choice and decision-making processes. There is also a need for in-depth studies to uncover the communications processes followed within higher education institutions and to determine whether communication integration takes place within these institutions.

\section{CONCLUDING REMARKS}

The results of this study provide guidance to higher education institutions on the most preferred communication channels utilised during the institution selection process. It also provides guidance on how to use the classic communication model to select appropriate channels to communicate with different cultural and gender groups. The findings may serve as a starting point in how to apply limited budgets more efficiently. 


\section{REFERENCES}

Anisimova, T.A. 2007. The effects of corporate brand attributes on attitudinal and behavioural consumer loyalty. Journal of Consumer Marketing 24(7): 395-405.

Arpan, L.M., A.A. Raney and S. Zivnuska. 2003. A cognitive approach to understanding university image. Corporate Communications 8(2): 97-113.

Bonnema, J. and D.L.R. van der Waldt. 2008. Information and source preferences of a student market in higher education. International Journal of Education Management 22(4): 314-327.

Bradshaw, G.S., S. Espinoza and S. Hausman. 2001. The college decision-making of high-achieving students. College and University 77'(2): 15-22.

Braxton, J.M. 1990. How students choose colleges: The strategic management of college enrolments. San Francisco: Jossey-Bass.

Chapman, D.W. 1981. A model of student college choice. Journal of Higher Education 52(5): 490-505.

Chester, RA. 2005. EDU Internet strategies to market higher education organisations. Press release (EDU-IS).

Christensen, L.T., A.F. Firat, and S. Torp. 2008. The organization of integrated communications: Toward flexible integration. European Journal of Marketing 42(3/4): 423-452.

Coetzee, M.D. and E. Liebenberg. 2004. The influence of corporate reputation on the choice of the University of Pretoria as a preferred higher education institution: A survey of high school learners in the Pretoria region. Honours thesis, University of Pretoria.

Cosser, M. and J. du Toit. 2002. From school to higher education: Factors affecting the choice of Grade12 learners. Cape Town: HSRC Publishers.

Du Plessis, PJ. and G.G. Rousseau. 2005. Buyer behaviour: A multi-cultural approach (3rd edition). Cape Town: Oxford.

Espinoza, S., C. Bradshaw and C. Hausman. 2002. The importance of college factors from the perspective of high school counsellors. College and University 77(4): 19-24.

Gemma, C. 2002. City and Guilds' bid to beat the old school. Marketing Week, September.

Goff, B., V Patino and G. Jackson. 2004. Preferred information sources of high school students for community colleges and universities. Community College Journal of Research and Practice 28(10): 795-803.

Hair, J.F., W.C. Black, BJ. Babin, R.E. Anderson and R.L. Tatham. 2006. Multivariate data analysis. New Jersey: Pearson Prentice Hall.

Hawkins, D.I., R. J. Best and K. A. Coney. 2004. Consumer behaviour: Building marketing strategy $\left(9^{\text {th }}\right.$ edition). New York: McGraw-Hill.

Hesel, R.A. 2004. Campus visits drives college choice. StudentPoll 5(5).

http://www.artsci.com/StudentPOLL/v5n5/publishers_note.htm (accessed 15 May 2009).

Hossler, D. and K.S. Gallagher. 1987. Studying student college choice: A three phase model. College and University 62(3): 207-221.

Hoyt, J.F. and A.B. Brown. 2003. Identifying college choice factors to successfully market your institution. College and University 78(4): 3-5.

Ihator, A.S. 2004. Corporate communication: Reflections on twentieth-century change. Corporate Communications: An International Journal 9(3): 243-253.

Ivy, J. 2001. Higher education institution image: A correspondence analysis approach. The International 
Journal of Educational Management 15(6): 276-282.

Jones, M. 2002. The effectiveness of marketing communication strategies employed by universities and technikons in the Cape Peninsula with specific reference to career exhibitions and open days in attracting first year students. Master's dissertation, University of Cape Town.

Kotler, P. and K. Fox. 1995. Strategic marketing for educational institutions. Englewood Cliffs, NJ: Prentice Hall.

Lamb, C.W., J.F. Hair, C. McDaniel, C. Boshoff and N.S. Terblanche. 2004. Marketing management (2nd edition). Cape Town: Oxford University Press.

Laurer, L.D. 2006. Advancing higher education in uncertain times. http://www2.university (accessed 6 December 2006).

Lovelock, C.H. and Wright, L. 1999. Principles of services marketing and management. Upper Saddle River, NJ: Prentice-Hall.

Maringe, F. 2006. University and course choice: Implications for positioning, recruitment and marketing. International Journal of 'Educational Management 20(6): 466-479.

McColl-Kennedy, J.R. 2003. Services marketing a managerial approach. Australia: John Wiley.

McDonough, P.M. 1994. Buying and selling higher education: The social construction. The Journal of Higher Education 65(4): 427-467.

Mitra, A.K., M.C. Reiss and L.M. Capella. 1999. An examination of perceived risk, information search and behavioural intentions in search. Journal of Services Marketing 13(3): 208-228.

Mouwen, K. 2002. Strategy, structure and culture of the hybrid university: Towards the university of the 21st century. Higher Education and Management 6(1): 47-56.

Primary Research Group. 2007. The survey of college marketing programmes. http://www.primaryresearch.com/release-200704276 (accessed 20 December 2008).

Rindfleish, J.M. 2003. Segment profiling: Reducing strategic risk in higher education managements. Journal of Higher Education Policy and Management 25(2): 147-159.

Ross, M., J.G. Heany and M. Cooper. 2007. Institutional and managerial factors affecting international student recruitment management. International Journal of Educational Management 21(7): 593-605.

Schiffman, L.G. and L.L. Kanuk. 2004. Consumer behaviour (8th edition). Upper Saddle River, NJ:Prentice Hall.

Seymour, L. 2000. Giving the Web the new college try: Students online surf to sample life on campus. The Washington Post, 28 March: 11.

Strydom, J., C. Jooste, PT. du Plessis and M. Cant. 2006. Marketing management (5th edition). Cape Town: Juta.

Tabachnick, B.G. and L.S. Fidell. 2001. Using multivariate statistics (4th edition). New York: Harper Collins.

Tarnovskaya, V, U. Elg and S. Burt. 2008. The role of corporate branding in a market driving strategy. International Journal of Retail \& Distribution Management 36(11): 941-965.

Torp, S. 2009. Integrated communications: From one look to normative consistency. Corporate Communications: An International Journal 14(2): 190-206.

Warren, E. 1994. Schools pull out the stops to lure business students. Los Angeles Business Journal April (18).

Weidlich, T. 2001. E-mail prospecting: 101 colleges and universities use for recruiting. http://www. findarticles.eom/p/articles/mi_m3815/is_l_13/ai_69415983 (accessed 1 December 2005).

Wells, W.D. 1996. Consumer behaviour. New York: John Wiley and Sons. 
Whyte, A. 2001. Positioning Australian universities for the twenty first century. Open Learning 16(1):27-33.

Zeithaml, V and M. Bitner. 2000. Services marketing (3rd edition). Boston: McGraw-Hill. 